\title{
A Republican Potential: The Rise and Fall of the German Democratic Party in Hof-an-der-Saale, 1918-1920
}

\begin{abstract}
Alex Burkhardt
ABSTRACT. In January 1919, the Bürgertum of the Bavarian town of Hof voted overwhelmingly for the left-liberal German Democratic Party (Deutsche Demokratische Partei, DDP). But the following summer, in the Reichstag elections of June 1920, the Democrats sustained significant losses against the right-wing nationalist Bavarian Middle Party (Bayerische Mittelpartei, BMP). This article explores the rise and fall of the DDP in Hof by showing that a pro-republican politics initially proved popular among the local Bürgertum, until its credibility was undermined and ultimately destroyed by a series of devastating crises: the Bavarian Räterepublik of April 1919, the publication of the Versailles Treaty a month later, and the revolutionary and counterrevolutionary convulsions triggered by the Kapp Putsch in March 1920. This article concludes that political violence and a burgeoning confrontation between bürgerliche and socialist milieus were the key factors in explaining the eclipse of left-liberalism in Hof during the first years of the Weimar Republic.
\end{abstract}

Im Januar des Jahres 1919 wählte das Bürgertum der bayerischen Stadt Hof mit großer Mehrheit die linksliberale Deutsche Demokratische Partei (DDP). Doch im darauffolgenden Sommer, bei den Reichstagswahlen im Juni 1920, erlitten die Demokraten erhebliche Verluste zugunsten der rechtsgerichteten, nationalistischen Bayerischen Mittelpartei. Im vorliegenden Aufsatz werden Aufstieg und Fall der DDP in Hof erklärt, indem gezeigt wird, dass eine pro-republikanische Politik zunächst vom dortigen Bürgertum befürwortet wurde, diese allerdings dann ihre Glaubwürdigkeit aufgrund einer Reihe schwerer Krisen einbüßte und gänzlich verlor (die Bayerische Räterepublik im April 1919, die Veröffentlichung des Versailler Vertrages im darauffolgenden Monat und die revolutionären und konterrevolutionären Unruhen im Zuge des Kapp Putsches im März 1920). Wie herausgestellt wird, sind letztlich die politische Gewalt und die beginnende Konfrontation zwischen bürgerlichen und sozialistischen Milieus die Schlüsselfaktoren gewesen, die den Niedergang des Linksliberalismus während der ersten Jahre der Weimarer Republik in Hof erklären.

$\mathrm{S}$ TORIES need heroes and villains, and the Weimar Republic, it seems, is little different. As Peter Fritzsche has suggested, the "favorite sons and daughters" of Weimar historiography have traditionally been "working-class socialists," while one review of a notable book about political violence during the republic found that it "repeatedly

The research for this article was carried out as part of my $\mathrm{PhD}$ thesis, which was completed at (and funded by) the University of St. Andrews, which I would like to thank for its support and generosity. I am further grateful to my doctoral supervisors, Riccardo Bavaj and Conan Fischer, as well as to Milena Elsinger, Arnd Kluge, Thomas Rohkrämer, Andrew Port, and the two anonymous reviewers for their helpful readings, comments, and criticisms of this article. 
implies" that workers were "the good guys."1 Conversely, the role of villain is generally assigned to the protestant Bürgertum - the bourgeoisie of Germany's small rural towns and villages that made up the Nazis' core constituency. ${ }^{2}$ Several scholars have depicted this section of the population as fundamentally reactionary and anti-republican, pointing to its "extreme autism" and arguing that the republic failed "in the final analysis because large segments of the bourgeoisie were unable to free themselves of their outdated, authoritarian frame of mind." 3 Such a narrative overlooks, however, the fact that, in the January 1919 elections to the National Assembly — the first of the Weimar period - much of the protestant Bürgertum voted in large numbers for a party that was anything but authoritarian or radical nationalist: the German Democratic Party (Deutsche Demokratische Partei, DDP), progressive republicans who advocated women's rights, cooperation with the moderate left, and international reconciliation. Only later, in the Reichstag elections of summer 1920, did Germany's protestant Bürgertum begin to desert left-liberal republicanism and shift in the direction of the radical nationalist right. ${ }^{4}$

But can the January 1919 results be taken as proof against the German Bürgertum's fundamental "autism" and "authoritarianism"? In fact, some sixty years of scholarship on German liberalism has not produced a consensus on this question. In the 1960s and 1970s, many historians depicted initial bürgerliche support for the DDP as a cynical attempt to prevent a Social Democratic parliamentary majority amid the prevailing circumstances of an apparently triumphant revolution, after which the inherently "reactionary" German bourgeoisie deserted the Democrats for their natural home - the nationalist right. ${ }^{5}$ By contrast, Lothar Albertin argued in a 1971 article that the DDP declined because it was insufficiently radical, that it failed to reform German society along the kind of democratic lines many of its members wanted, and that it was too beholden to heavy industry. ${ }^{6}$ Similarly, Larry Eugene Jones's prodigious scholarship on the disintegration of Weimar liberalism has tended to emphasise the devastating effects of the hyperinflation, rather than the

\footnotetext{
${ }^{1}$ See Peter Fritzsche, “Did Weimar Fail?," Journal of Modern History 68, no. 3 (1996): 630; Peter D. Stachura, review of Dirk Schumann, Politische Gewalt in der Weimarer Republik 1918-1933: Kampf um die Strasse und Furcht vor dem Bürgerkrieg, in American Historical Review 108, no. 1 (2003): 275-76.

${ }^{2}$ On the centrality of this section of the population to Nazi electoral success, see Riccardo Bavaj, Der Nationalsozialismus: Entstehung, Aufstieg und Herrschaft (Berlin: be.bra, 2016), 21-24.

${ }^{3}$ See Hans Mommsen, Die Verspielte Freiheit: Der Weg der Republik von Weimar in den Untergang, 1918 bis 1933 (Frankfurt/Main: Ullstein, 1990), 9; Dirk Schumann, Political Violence in the Weimar Republic, 1918-1933: Fight for the Streets and Fear of Civil War, trans. Thomas Dunlap (New York: Berghahn, 2009), 314.

${ }^{4}$ For a detailed account of the history of the DDP, see Erich Matthias and Rudolf Morsey, "Die Deutsche Staatspartei," in Das Ende der Parteien 1933, ed. Erich Matthias and Rudolf Morsey (Düsseldorf: Droste, 1960), 31-97.

${ }^{5}$ See, e.g., Heinrich August Winkler, Mittelstand, Demokratie und Nationalsozialismus: Die politische Entwicklung von Handwerk und Kleinhandel in der Weimarer Republik (Cologne: Kiepenheuer \& Witsch, 1972); Hartmut Schustereit, Linksliberalismus und Sozialdemokratie in der Weimarer Republik: Eine vergleichende Betrachtung der Politik von DDP und SPD, 1919-1930 (Düsseldorf: Pädagogischer Verlag Schwann, 1975); Ernst Portner, "Der Ansatz zur demokratischen Massenpartei im Deutschen Linksliberalismus," Vierteljahrshefte für Zeitgeschichte 13, no. 2 (1965): 150-61.

${ }^{6}$ Lothar Albertin, "German Liberalism and the Foundation of the Weimar Republic: A Missed Opportunity?," in German Democracy and the Triumph of Hitler: Essays in Recent German History, ed. Anthony James Nicholls and Erich Matthias (London: Allen and Unwin, 1971), 29-46. For a more dogmatically Marxist variant on this argument, see Reinhard Opitz, Der deutsche Sozialliberalismus 1917-1933 (Cologne: Pahl-Rugenstein, 1973).
} 
German Bürgertum's putative "autism."7 Even relatively recent studies evince considerable disagreement on the essential character of the DDP: whereas some historians have argued that German left-liberalism, in stark contrast to its British or French variants, was underpinned by authoritarian, völkisch, even proto-fascist principles, other recent biographical and intellectual profiles of leading Weimar-era Democrats have tended to emphasise that these were genuine, "universalist," constitutional liberals. ${ }^{8}$

This continued ambiguity about the essential character of the German Democrats and the significance of their success in January 1919 is unfortunate, because a full understanding of this issue is crucial not only to our characterization of the German bourgeoisie, but also to our overall conceptualization of the entire Weimar period. If we take bürgerliche support for the DDP as evidence for an authentic, if cautious, endorsement of democratic values, then the republic's initial chances for survival begin to seem better, and its ultimate end in 1933 not necessarily set in stone from 1918 onward — a notion very much in keeping with much recent scholarship. ${ }^{9}$ But if we see the DDP's success in January 1919 as expressive of short-term opportunism - or, indeed, veiled völkisch authoritarianism-on the part of an irredeemably reactionary Bürgertum, then the ghosts of more traditional, deterministic, "glitter-and-doom" paradigms about the Weimar Republic are conjured up once more. ${ }^{10}$

This article thus proposes to look afresh at the early history of the DDP to ascertain the reasons not only for its success among the German Bürgertum in January 1919, but also for its rapid decline thereafter. The analysis focuses on the relationship between the Democrats and the protestant Bürgertum in a single locale: Hof-an-der-Saale, a small town of forty thousand people in Bavarian Upper Franconia. This microhistorical approach is justified by the fact that the small towns and villages of the German provinces were the natural habitat of the "national-protestant milieu" that made up the bulk of the DDP's (and later the NSDAP's)

\footnotetext{
${ }^{7}$ See, e.g., Larry Eugene Jones, "Inflation, Revaluation, and the Crisis of Middle-Class Politics: A Study in the Dissolution of the German Party System, 1923-28," Central European History 12, no. 2 (1979): $143-68$.

${ }^{8}$ See Eric Kurlander, The Price of Exclusion: Ethnicity, National Identity, and the Decline of German Liberalism, 1898-1933 (New York: Berghahn, 2006). Kurlander's view is reminiscent of an older study: Robert A. Pois, The Bourgeois Democrats of Weimar Germany (Philadelphia, PA: American Philosophical Society, 1976). Conversely, the "authentic" liberalism of German Democrats is especially apparent from the numerous profiles of prominent left-liberals who defected to the Social Democrats during the Weimar Republic; these are collected in Detlef Lehnert, ed., Vom Linksliberalismus zur Sozialdemokratie: Politische Lebenswege in historischen Richtungskonflikten, 1890-1945 (Cologne: Böhlau Verlag, 2015).

${ }^{9}$ Much scholarship written in the last ten years has problematized the narrative- which ran throughout both contemporary discourse and the interpretations of later historians - claiming that the Republic was permanently in "crisis" and thus inevitably doomed. Useful summaries of this literature can be found in Moritz Föllmer, "Which Crisis? Which Modernity? New Perspectives on Weimar Germany," in Beyond Glitter and Doom: The Contingency of the Weimar Republic, ed. Jochen Hung, Godela Weiss-Sussex, and Geoff Wilkes (Munich: Ludicium, 2012), 19-31; Rüdiger Graf, "Either-Or: The Narrative of 'Crisis' in Weimar Germany and in Historiography," Central European History 43, no. 4 (2010): 592-615. Other scholars have challenged the traditional view of Weimar as a "Republic without Republicans" (and thus inevitably doomed), highlighting instead the relative success of Weimar governments in facilitating the development of a popular democratic culture. Notable examples here include Manuela Achilles, "With a Passion for Reason: Celebrating the Constitution in Weimar Germany," Central European History 43, no. 4 (2010): 666-89; Nadine Rossol, "Performing the Nation: Sports, Spectacles, and Aesthetics in Germany, 1926-1936," Central European History 43, no. 4 (2010): 616-38. For the democratic potentialities inscribed in parliamentary practice and communication, see Thomas Mergel, Parlamentarische Kultur in der Weimarer Republik: Politische Kommunikation, symbolische Politik und Öffentlichkeit im Reichstag (Düsseldorf: Droste, 2002).

${ }^{10}$ This was the title of a collection of essays that called into question precisely such narratives: Hung, Weiss-Susses, and Wilkes, Beyond Glitter and Doom.
} 
electorate. ${ }^{11}$ Indeed, historians have already built up an extensive body of literature on the radicalization of this section of the population during the Weimar Republic. ${ }^{12}$ This literature offers considerable insight into bürgerliche radicalization throughout the entire period of the republic (and sometimes beyond), but it does not focus specifically on the fortunes of the German Democratic Party within this milieu. Conversely, studies of regional branches of the DDP tend to be primarily party-based analyses. ${ }^{13}$ Consequently, we lack detailed information on the sociological and discursive anchorage of the DDP within Germany's nationalprotestant milieu, and on the context of the party's rise and fall in those constituencies that initially backed it.

Hof-an-der-Saale has been chosen as a case study because it was highly typical of the kind of small, provincial, Protestant setting that initially evinced strong bürgerliche backing for the Democrats in the January 1919 elections-only later to radicalize dramatically in a nationalist direction (Table 1). ${ }^{14}$ Hof was a profoundly Protestant town in a region known for its aggressively evangelical tradition, but it also had a strong industrial heritage and a history of burgeoning class division and conflict. ${ }^{15}$ Focusing on this town thus allows us to address the two questions that are central to this article: how successful was the DDP in establishing itself and setting the political and ideological agenda in the kind of town where the national-protestant milieu radicalized rapidly in the first years of the republic; and, second, what factors and conditions facilitated not only Democrat successes within this setting, but also the party's fall from grace and replacement by more radical right-wing alternatives?

\footnotetext{
${ }^{11}$ This concept of the "socio-moral milieu" or "camp" draws on M. Rainer Lepsius, Demokratie in Deutschland: Soziologisch-historische Konstellationsanalysen. Ausgewählte Aufsätze (Göttingen: Vandenhoeck \& Ruprecht, 2011); Karl Rohe, Wahlen und Wählertraditionen in Deutschland: Kulturelle Grundlagen deutscher Parteien und Parteiensysteme im 19. und 20. Jahrhundert (Frankfurt/Main: Suhrkamp, 1992). The specific appellation "national-protestant milieu" is taken from Manfred Kittel, "Weimar" im evangelischen Bayern. Politische Mentalität und Parteiwesen, 1918-1933. (Munich: Bayerische Landeszentrale für Politische Bildungsarbeit, 2001).

${ }^{12}$ This extensive literature includes Rudy Koshar, Social Life, Local Politics, and Nazism: Marburg, 1880-1935 (Chapel Hill: University of North Carolina Press, 1986); Peter Fritzsche, Rehearsals for Fascism: Populism and Political Mobilization in Weimar Germany (New York: Oxford University Press, 1990); Siegfried Weichlein, Sozialmilieus und politische Kultur in der Weimarer Republik: Lebenswelt, Vereinskultur, Politik in Hessen (Göttingen: Vandenhoeck \& Ruprecht, 1996); Wolfram Pyta, Dorfgemeinschaft und Parteipolitik, 1918-1933: Die Verschränkung von Milieu und Parteien in den protestantischen Landgebieten Deutschlands in der Weimarer Republik (Düsseldorf: Droste, 1996); Claus-Christian Szejnmann, Nazism in Central Germany: The Brownshirts in 'Red' Saxony (New York: Berghahn Books, 1999); Frank Bösch, Das konservative Milieu: Vereinskultur und lokale Sammlungspolitik in ost- und westdeutschen Regionen (1900-1960) (Göttingen: Wallstein, 2002); Helge Matthiesen, Bürgertum und Nationalsozialismus in Thüringen: Das bürgerliche Gotha von 1918 bis 1930 (Jena: G. Fischer, 1994).

${ }^{13}$ See, e.g., Joachim Stang, Die Deutsche Demokratische Partei in Preussen, 1918-1933 (Düsseldorf: Droste, 1994); Gerhard Menk, Politischer Liberalismus in Hessen zwischen Weimarer Republik und Nachkriegszeit: Rudolf Büttner, Margarete Grippentrog und die Deutsche Demokratische Partei Fuldas (Fulda: Parzellers Buchverlag, 2012).

${ }^{14}$ For a prime example of this phenomenon, see Matthiesen, Bürgertum und Nationalsozialismus in Thüringen.

${ }^{15}$ Upper Franconia was a profoundly Protestant region, and, in Hof in particular, political Catholicism played almost no appreciable role in local politics; see Kittel, "Weimar" im evangelischen Bayern. For Hof's particular history of Protestantism and the irrelevance of political Catholicism, see Axel Herrmann, Kleine Hofer Stadtgeschichte (Regensburg: Pustet, 2012). On Hof's endemic class divisions, and on the nineteenth-century development of Hof into a significant industrial center, see Rudolf Baumgarten, "Die Hofer Sozialdemokratie vom Vorabend des ersten Weltkrieges bis zum geschlossenen Übertritt zur USPD (Oktober 1917)" (Würzburg: Schriftliche Hausarbeit zur Wissenschaftlichen Prüfung für das Lehramt an den Gymnasien, 1980).
} 
Table 1. Landtag and Reichstag Election Results in Hof, 1919-1924

\begin{tabular}{|c|c|c|c|c|c|c|c|}
\hline & \multicolumn{2}{|c|}{ Jan. 1919} & \multicolumn{2}{|c|}{ June 1920} & \multicolumn{2}{|c|}{ May 1924} & \multirow{2}{*}{ 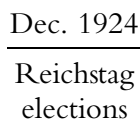 } \\
\hline & $\begin{array}{l}\text { Reichstag } \\
\text { elections }\end{array}$ & $\begin{array}{l}\text { Landtag } \\
\text { elections }\end{array}$ & $\begin{array}{l}\text { Reichstag } \\
\text { elections }\end{array}$ & $\begin{array}{l}\text { Landtag } \\
\text { elections }\end{array}$ & $\begin{array}{l}\text { Reichstag } \\
\text { elections }\end{array}$ & $\begin{array}{l}\text { Landtag } \\
\text { elections }\end{array}$ & \\
\hline MSPD & 989 & 1516 & 1659 & 1466 & $\mathrm{~N} / \mathrm{A}$ & $\mathrm{N} / \mathrm{A}$ & $\mathrm{N} / \mathrm{A}$ \\
\hline USPD & 11,129 & 10,409 & 10,729 & 10,820 & 7437 & 7534 & 9205 \\
\hline DDP & 6433 & 6333 & 5544 & 6036 & 663 & 709 & 831 \\
\hline $\mathrm{BMP}^{*}$ & 190 & 131 & 1636 & 1278 & 1176 & 32 & 4829 \\
\hline NSDAP/VB & $\mathrm{N} / \mathrm{A}$ & $\mathrm{N} / \mathrm{A}$ & $\mathrm{N} / \mathrm{A}$ & $\mathrm{N} / \mathrm{A}$ & 8426 & 9898 & 3510 \\
\hline BVP & 914 & 1193 & 968 & 1000 & 958 & 756 & 985 \\
\hline KPD & $\mathrm{N} / \mathrm{A}$ & $\mathrm{N} / \mathrm{A}$ & 157 & $\mathrm{~N} / \mathrm{A}$ & 711 & 1012 & 374 \\
\hline $\begin{array}{c}\text { BBB (Bayerische } \\
\text { Bauernbund) }\end{array}$ & $\mathrm{N} / \mathrm{A}$ & 4 & $\mathrm{~N} / \mathrm{A}$ & 3 & $\mathrm{~N} / \mathrm{A}$ & 1202 & $\mathrm{~N} / \mathrm{A}$ \\
\hline
\end{tabular}

*Common ticket with German People's Party in Landtag elections.

Sources: Christoph Rabenstein, Politische und publizistische Strömungen in einer Stadt Oberfrankens: Hof 1918-1924. Ein Beitrag zur politischen Willensbildung in der Frühphase der Weimarer Republik (Bayreuth: H.-J. Hagen, 1986); Arnd Kluge, "Wie nationalsozialistisch war die Hofer Region?," Miscellanea curiensia XI (Hof: Nordoberfränkischer Verein, 2015), 65-93.

In explaining the erosion and ultimate disintegration of support for the DDP in Hof, this article stresses not fundamental bürgerliche illiberalism or the debilitating effects of the hyperinflation, but rather the role of revolutionary and counterrevolutionary violence. Indeed, the centrality of political violence to the overall course of the German revolution has recently enjoyed renewed interest from historians who have shown an increasing tendency to depict the early years of the Weimar Republic as a period of virtual civil war. Robert Gerwarth, for example, has explicated the growing links between paramilitarism and civilian politics during the German Revolution, while Dirk Schumann and Mark Jones have both shown how a pervasive perception of all-permeating political violence, one transmitted through the media and even rumor, contributed to profound processes of political radicalization. ${ }^{16}$ Yet, no sustained attempt has been made to analyze the repercussions of this perception of omnipresent violence for the fortunes of the German Democrats in one of the party's small-town bastions. It is this lacuna in the literature that the following article addresses.

It begins with the outbreak of the German Revolution in November 1918, because it was during this period when Germany's (and Hof's) left-liberals appeared to have been handed a

\footnotetext{
${ }^{16}$ Gerwarth has been prolific here; see especially "The Central European Counter-Revolution: Paramilitary Violence in Germany, Austria and Hungary after the Great War," Past E Present 200, no. 1 (2008): 175-209; Robert Gerwarth and John Horne, "Bolshevism as Fantasy: Fear of Revolution and Counter-Revolutionary Violence, 1917-1923," in War in Peace: Paramilitary Violence in Europe after the Great War, ed. Robert Gerwarth and John Horne (Oxford: Oxford University Press, 2012), 40-52. For a summary of his own findings, see Dirk Schumann, "Politische Gewalt in der frühen Weimarer Republik (1919-1923) und ihre Repräsentation in der politischen Tagespresse," in Politische Kultur und Medienwirklichkeiten in den 1920er Jahren, ed. Ute Daniel et al. (Munich: Oldenbourg, 2010), 279-311. A significant recent contribution is Mark Jones, Founding Weimar: Violence and the German Revolution of 1918-1919 (Cambridge: Cambridge University Press, 2016). For a less recent but still penetrating study of how perceived (and real) civil war conditions during the German revolution contributed to political radicalization in Berlin, see Andreas Wirsching, Vom Weltkrieg zum Bürgerkrieg? Politischer Extremismus in Deutschland und Frankreich, 1918-1933/39: Berlin und Paris im Vergleich (Munich: Oldenbourg, 1999).
} 
historic opportunity to shape the Reich according to their values and convictions. The following three sections show that the fragile but significant democratic consensus created in the initial months of the revolution was first undermined and then destroyed by a series of crises that hit the town beginning in the spring of 1919, chief among them several confrontations with the increasingly radical working-class milieu and a burgeoning perception of pervasive political violence. An escalating conflict between workers and burghers in Hof, as well as outrage over the Treaty of Versailles, discredited the vision of reconciliation and compromise propounded by the Democrats, and allowed more extremist elements within the local Bürgertum to assert credibly once again their interpretation of events. The final section illustrates the cumulatively devastating effects of these crises on Democratic support during the 1920 Reichstag Elections.

\section{The Triumph of Hof's Left-Liberals after World War I}

Hof began to industrialize extremely rapidly during the mid-nineteenth century and, by the turn of the twentieth, it had become one of the biggest textile manufacturing centers in Bavaria. This process produced deep social divisions between an industrial working class concentrated in tenement blocks along the Saale River, and a more professionally diffuse Bürgertum united by its national-protestant outlook and common civic and political culture. ${ }^{17}$ By the early twentieth century, Hof had become a political, social, and cultural battleground between these two distinct socio-moral milieus. Because of the relative absence of Catholics in Hof, and thus the striking weakness of political Catholicism, these social divisions took the form of a two-way battle for political influence between the Social Democrats (Sozialdemokratische Partei Deutschlands, SPD) and National Liberals (Nationalliberale Partei, NLP). ${ }^{18}$ Yet, this was not an ideologically homogenous community - despite the national-protestant milieu's almost unanimous backing of the National Liberals, their common integration into a range of civic associations, and their almost unanimous readership of the pro-monarchist Hofer Anzeiger. ${ }^{19}$ It was certainly home to chauvinist, nationalist, and monarchist sentiments, but there were also democratic reformists within its ranks who had ties to the left-liberal Progressive People's Party (Fortschrittliche Volkspartei, FVP) and who advocated a reform of the constitution and reconciliation with Social Democracy. ${ }^{20}$

The outbreak of the war in 1914, and the sufferings and privations of the subsequent fouryear period, threw these divisions within Hof's national-protestant milieu into sharp relief. In August 1914, several local burghers dressed in the uniforms of nationalist fraternities gathered outside the offices of the Anzeiger to sing "The Watch on the Rhine" and demand aggressive action against Germany's enemies, while others attended a peace rally organized by the Social Democrats. ${ }^{21}$ Similarly, while some of Hof's burghers joined a local branch of the radical

\footnotetext{
${ }^{17}$ See Wolfgang Zorn, "Probleme der Industrialisierung Oberfrankens im 19. Jahrhundert," in Jahrbuch für fränkische Ländesforschung 29 (Neustadt/Aisch: Institut für fränkische Landesforschung an der Universität Erlangen-Nürnberg, 1969): 307; Stadtarchiv Hof (StaHf), M.80, Julius Kellermann, "Einiges aus der Hofer Wirtschaft der letzen 40 Jahre (1918-1958)," 1958.

${ }^{18}$ For an analysis of this political and confessional pattern, see Kittel, "Weimar" im evangelischen Bayern, 33.

${ }^{19}$ Rolf Hoermann, Der Hofer Anzeiger. Das Werden und Wirken einer Heimatzeitung in der bayerischen Ostmark (unpublished Phil. dissertation, University of Munich, 1938).

${ }^{20}$ Herrmann, Kleine Hofer Stadtgeschichte, 76; Baumgarten, Die Hofer Sozialdemokratie, 33.

${ }^{21}$ Baumgarten, Die Hofer Sozialdemokratie, 88.
} 
nationalist and annexationist Fatherland Party (Deutsche Vaterlandspartei, DVLP), others agitated for peace and called for constitutional reform along democratic lines. ${ }^{22}$ These simmering antagonisms within Hof's national-protestant milieu finally came to a head in the autumn of 1918. Earlier that year, General Erich von Ludendorff's spring offensive had failed, triggering a gradual dissolution of the German Western Front, which culminated in the November Revolution and the abdication (and ignominious flight to Holland) of the kaiser. In Munich, the Wittelsbach monarchy was deposed on November 12 after a bloodless coup directed by Kurt Eisner, a member of the Independent Social Democrats (Unabhängige Sozialdemokratische Partei Deutschlands, USPD). This gave the signal to Hof's USPD to form their own workers' and soldiers' council and proclaim the advent of the revolution in the town. ${ }^{23}$

All of this seemed to vindicate those among Hof's Bürgertum who had been democratic reformists and advocates of the 1917 Reichstag "Peace Resolution" (which had called for a "peace without annexations"), while badly discrediting the radical nationalist proponents of an "annexationist peace." The latter conspicuously melted away as the revolution gathered momentum in November 1918. In the immediate aftermath of these tumultuous events, the fulcrum of bürgerliche political life in Hof became the local branch of the German Democratic Party, which was formed by left-liberals on December 8, 1918. ${ }^{24}$ In the first eighteen months after World War I, the DDP effectively controlled the political culture of Hof s nationalprotestant milieu. A Democratic councillor, Otto Ernst, edited the most widely read bürgerliche newspaper, the Hofer Anzeiger; DDP meetings regularly packed the town's biggest halls; Democrats were highly influential on the municipal council; and the party's Landtag delegate, Karl Schrepfer, was extremely well-connected and respected in local business circles.

The Hofer DDP quickly made its attitude toward the revolution and the end of the monarchy abundantly apparent. At a packed meeting in Pfaff's Colosseum on December 12, a local doctor and DDP delegate named Gottlieb Scheiding declared that "the new times demand new forms, and we must all now try to behave democratically." For editor Otto Ernst, the revolution was something to be celebrated: far from being "merely proletarian," it could not have occurred without the "implicit connivance" of the middle class. ${ }^{25}$ Ernst argued in the Hofer Anzeiger that Germany's burghers "no longer yearn for the return of our former rulers," and that, with the monarchy gone, "the bürgerliche element" was "called on to cooperate," for they had "seen in the revolution a phenomenon that was not entirely unsympathetic"-one to which they "would remain true" if it would bring the "basis and possibility for a socially and economically tolerable existence."26

What this meant, in practice, was wide-ranging cooperation with the Majority Social Democrats (Mehrheitssozialdemokratische Partei Deutschlands, MSPD) in the construction of a republic, a theme that local Democrats constantly reiterated. "With the reactionary right

\footnotetext{
${ }^{22}$ See Christoph Rabenstein, Politische und publizistische Strömungen in einer Stadt Oberfrankens: Hof 1918-1924. Ein Beitrag zur politischen Willensbildung in der Frühphase der Weimarer Republik (Bayreuth: H.-J. Hagen, 1986), 56-57.

${ }^{23}$ Ibid., 56-60.

${ }^{24}$ Rudolf Macht, Geschichte der Hofer Arbeiterbewegung Band $3 / 1$ (1918-1923): Spaltung (Hof: Selbstverlag, 1991), 45.

${ }^{25}$ StaHf, ZA.2430, Dokumente der Deutschen Demokratischen Partei Hofs, 1918-1924 (henceforth DDP Hofs), "Hof, 12. Dezember," Dec. 12, 1918.

26“"Wohin treiben Wir?," Hofer Anzeiger (henceforth HA), Dec. 29, 1918.
} 
discredited, only the Social Democrats can now be considered our rivals," declared Ernst at the party's founding meeting, "and we don't want to attack these rivals, only to create a partition between us." Herr Haack, a Democratic delegate to the Landtag, similarly insisted that the party was "determined to move to the left," for "our path goes a long way with Social Democracy" in wishing to create a genuinely democratic republic. ${ }^{27} \mathrm{~A}$ few days later, at a meeting of the Liberal Society, Dr. Scheiding declared himself pleased that "no antagonistic attitude toward the Socialists had been adopted" by local Democrats, imploring local burghers to "learn to see the good in our Socialist rivals" and "not deny ourselves the chance to speak with them" - a statement that earned him a healthy round of applause. ${ }^{28}$ Local Democrats differentiated carefully between moderates and radicals on the left, maintaining that Germany's salvation could only come about through a principled cooperation between the reasonable elements among both the Bürgertum and the working classes. An early circular of the local Democrats maintained that the party "had many things in common with the Majority Social Democrats, because they also desire a calm construction of the political system in a republican form," whereas "we have nothing in common with the Independents (USPD), who want to transform everything in a single bound."29

Far from being a point of anti-socialist concentration for Hof s burghers, the local DDP turned its fire much more determinedly on the fallen monarchical system. Otto Meisner, a local lawyer and municipal councillor, described the imperial regime as a "totally inauthentic system" that had "broken its trust" with the German people, while Democratic circulars prior to the January 1919 elections conclusively committed the party to "a fight against all attempts to restore the old imperial state," while pledging a "removal of everything that was so damaging under the monarchy." ${ }^{30}$ This system, the proclamation argued, had "proven itself incapable of protecting the German people at a time of peril." 31 In light of this, it is not surprising that there was little trace of the anti-socialist, incipiently antisemitic "stab-in-the-back" legend in the discourse of Hof's national-protestant milieu. ${ }^{32}$ The outcome of the war, Schrepfer argued, was to blame not on the revolutionary left but on "the mistakes of our monarchy and our military dictators," the "power-crazed clique of Pan-Germans" who had "brought disaster" on the German people through their "prosecution of an aggressive war." 33

These sentiments found resonance among other leading figures within Hof's nationalprotestant milieu. In the Hofer Anzeiger, journalist Fritz Auer denounced Germany's

\footnotetext{
${ }^{27}$ StaHf, ZA.2430, DDP Hofs, "Die Gründung der Deutschen Volkspartei in Hof: Imposante Gründungsversammlung (Schluss)," Dec. 10, 1918. To add to any confusion, the left-liberal German Democratic Party (DDP) in Bavaria was initially called the German Peoples' Party (Deutsche Volkspartei, DVP) until October 1919-and is not to be confused with Gustav Stresemann's right-liberal DVP, which was a separate organization. For the sake of clarity, this article will refer only to the German Democratic Party. See Joachim Reimann, "Der Politische Liberalismus in der Krise der Revolution," in Bayern im Umbruch, ed. Karl Bosl (Oldenbourg: Oldenbourg Wissenschaftsverlag, 1969), 173-85.

${ }^{28}$ StaHf, ZA.2430, DDP Hofs, “Hof, 12 Dezember,” Dec. 12, 1918.

${ }^{29}$ StaHf, ZA.2430, DDP Hofs, "Hof, 11. Januar, ” Jan. 11, 1919.

${ }^{30}$ StaHf, ZA.2430, DDP Hofs, "Deutsche Volkspartei Hof (Deutsche Demokratische Partei)," Dec 18, 1918.

${ }^{31}$ StaHf, ZA.2430, DDP Hofs, "Vor der Entscheidung!," Jan. 18, 1919.

${ }^{32} \mathrm{On}$ how widespread this idea was at the highest levels of both the German military and the Protestant church after the war, see Boris Barth, Dolchstosslegenden und politische Desintegration: Das Trauma der deutschen Niederlage im Ersten Weltkrieg 1914-1933 (Düsseldorf: Droste, 2003).

${ }^{33}$ StaHf, ZA.2430, DDP Hofs, "Wahlversammlung der deutschen Volkspartei, Hof 30. Dezember," Dec. 30, 1918; "Kandidatenwahl für die Nationalversammlung, Hof 19. Dezember,” Dec. 19, 1918.
} 
former "military dictators" for "striving further and further with their imperialistic impulses," and for pursuing goals that were more than the Reich's "actual strength could deliver," while a commemorative evening held by the District Teachers' Association to honor their twentyseven members killed during the war more or less developed into a pacifist gathering. ${ }^{34}$ The highlight of the evening was a speech by August Horn, a local schoolmaster who transformed his tribute to the fallen into a general denunciation of war and militarism. After voicing his sadness about not only the German dead but also "all victims of the war," he expressed the hope that, "in the future, we will fight with spiritual weapons rather than with murder," and he implored his audience to "abandon dreams of external power and greatness" in favor of a "better, more peaceful Reich." Horn's entire speech was splashed across two pages in two consecutive editions of the Hofer Anzeiger ${ }^{35}$

The fervent hope that a "League of Nations" would soon emerge to ensure that war would become a thing of the past further reflected this desire for international reconciliation. This was most evident in the writings of Eduard Herold, a politically active local teacher and poet, who wrote effusively about the prospect of such a League, which he described as "the most German thought ever thought." The German Volk, Herold maintained, had "historically contributed more" than any other people to this idea of a "concert of the peoples," a vision advocated by Germany's "greatest and most fertile spirits." Herold was further convinced that the Majority Socialist Democrats, as the champions of a "conservative" form of Social Democracy distinct from the "internationalism" of the radical left, could prove instrumental in Germany's accession to a new status in a remade world. ${ }^{36}$ The growing mood of pacifism and the desire for reconciliation with Germany's erstwhile enemies were grist to the mill of the Democratic Party, which published a proclamation explicitly rejecting the bürgerliche nationalism that had perceivably led to the war. Before 1914, "the Bürgertum of all countries" had been "locked into narrow nationalistic thinking," but "the terrible world war and unprecedented collapse" had "laid waste to these convictions," inducing Germany's burghers to "learn a new way, to change from a profound nationalism to an equally profound internationalism." 37

Overall, then, in the first months after World War I, the dominant middle-class party in Hof was an unmistakably progressive and liberal organization that championed the construction of a republic, called for cooperation with the Majority Social Democrats, denounced the imperial monarchy and blamed it for the loss of the war, and emphasized reconciliation in international politics. Certainly, it would be an exaggeration to suggest that Hof's entire national-protestant milieu had converted to republican democracy overnight and now subscribed to all these positions. But there is substantial evidence that such views enjoyed considerable currency in Hof after World War I; this includes the editorial content of the local middle-class newspaper, the writings of bürgerliche notables such as Eduard Herold, public speeches such as those by August Horn, and the overwhelming attendance at DDP meetings. Yet, the most compelling indication that the DDP's left-liberal profile was in keeping with the overall mood among Hof's middle classes came on January 19, 1919, when the bürgerliche districts voted overwhelmingly for the DDP, which won some six and a half thousand votes

\footnotetext{
34“"Objekt, nicht Subjekt!,” HA, Dec. 13, 1918.

35 "Dem Gedächtnis unserer gefallenen Helden!," HA, April 16 and April 17, 1919.

${ }^{36}$ Eduard Herold, Ein Jahr deutsche Republik (Munich: Hochschul Verlag, 1920), 4, 5, 36.

${ }^{37}$ StaHf, ZA.2430, DDP Hofs, “Zum Ersten Mai!,” May 1, 1919.
} 
(out of seven and a half thousand non-socialist votes) in the town alone. Conversely, the Bavarian Middle Party (Bayerische Mittel Partei, BMP), the state branch of the right-wing German Nationalist People's Party (Deutschnationale Volkspartei, DNVP), was rewarded for its affiliation with the monarchy and an "annexationist war" with a derisory 190 votes. ${ }^{38}$ Hof s burghers, it seemed, were prepared to give the new republic a chance.

\section{The Bavarian Räterepublik}

It was not until the spring of 1919, some three months after the DDP's dominant performance in the National Assembly elections, that cracks began to appear in the party's popularity in Hof. The causes of this lay in two devastating developments: the declaration of a Räterepublik in Munich by revolutionary radicals on April 6, and the publication of the terms of the Versailles Treaty on May 12. The following two sections show how these events produced a heightened sense among Hof's middle classes that they were confronted by grave threats to their very existence from both within and beyond Germany's borders, and just how problematic this sense of danger was for the Democrats and their model of politics.

The declaration of a Räterepublik in Munich on April 6, 1919, triggered revolutionary unrest across Bavaria. In Hof, the USPD-dominated Workers' and Soldiers' Council declared its full support for the revolutionaries, printing a proclamation that stated its intention to "assume control of all communal and political authority." 39 On April 8, the leaders of Hof's working-class movement convened stormy meetings with local civil servants and banks, at which the USPD's Arthur Mahr exalted the "Russian conditions" that now seemingly prevailed in Bavaria, while threatening those in attendance with unemployment or worse if they failed to comply "not just openly, but also out of inner conviction, with the new socialist-communist Räterepublik." 40 The next day, local farmers threatened to cut off the supply of foodstuffs to the town unless the Independents stood down, and the "Hofer Räterepublik" duly fizzled out without a shot fired. ${ }^{41}$

It is significant that this confrontation with the leaders of Hof s Socialist milieu occurred within the context of revolutionary unrest across Bavaria, all of which was fulsomely reported in the Hofer Anzeiger. For several weeks in April 1919, Hof s burghers were exposed every day in their newspaper, at political meetings, and even in the sermons of the Protestant pastor to continuous reports of "Bolshevik" violence and bloodshed in towns and cities across the state, some of which were only a brief train journey away. An apocalyptic anti-Bolshevism was injected into the discourse of the town's national-protestant milieu, which was abuzz with talk of "the rattling of machine guns" in a "week full of death," the "summary execution of bürgerliche hostages," and "Bolshevism" as a destructive and millenarian "religion of salvation." 42

\footnotetext{
${ }^{38}$ On the pre-1920 history of the Bavarian Middle Party, see Elina Kiiskinen, Die Deutschnationale Volkspartei in Bayern (Bayerische Mittelpartei) in der Regierungspolitik des Freistaats während der Weimarer Zeit (Munich: C.H. Beck Verlag, 2005).

39“An sämtliche Arbeiterräte," Oberfränkische Volkszeitung (henceforth OV), April 8, 1919.

40 "Lokales und aus dem Kreis," HA, April 14, 1919.

${ }^{41}$ Stadtarchiv Bamberg (StaBa), K3 Praes Reg. 1839, "Wochenberichte des Bezirksamt Hof-Land,” April 12, 1919. Also see Rabenstein, Politische und publizistische Strömungen, 68.

${ }^{42}$ See Evangelisches Dekanat Hof (EvaDekHf), Evangelisches Gemeindeblatt für den Dekanatsbezirk Hof (henceforth Evangelisches Gemeindeblatt), no. 6, "Auf Münchner Friedhöfen im Mai 1919," May 11, 1919; "Letzte Telegramme," HA, April 24, 1919; StaHf, ZA.2432, Dokumente über die Räterepublik in
} 
The vividness of the Bolshevist threat was enhanced by constant references to Soviet Russia, which became a grim premonition of what awaited the Reich if the revolutionaries were victorious. The month of April 1919 was punctuated by a series of anti-Bolshevist meetings at which speakers spoke darkly of "Russian conditions," described "Russia, where everything lies in ruins," as "an example of what is intended for us," and warned that, in the lands of the former Czarist empire, "famine reins, the death rate increases, and industry is at a standstill," with the land ruled by "an absolutist ruler-once named Czar Nicholas, now named Lenin," whose goal was to "eradicate the Bürgertum." The "principle of Bolshevism," one speaker argued, was that "we cannot create a better world until we have destroyed everything" - and this was precisely what Bavaria would learn unless the Räterepublik were speedily crushed. ${ }^{43}$ Indeed, besides presenting revolutionary Russia as a terrifying portent of what awaited Bavaria in the event of a successful Räterepublik, it was also frequently alleged that the Bolsheviks were the chief architects of what was happening in Bavaria-with the Hofer Anzeiger reporting on April 27 that, "in the last fourteen days, more than fifty Russians" had "made their way to Munich with instructions from the Moscow government to support the Communist movement." 44

This anti-Bolshevist discourse appeared in its purest form in the Aufrufe, a flood of written appeals by hastily assembled paramilitary groups exhorting the male citizens of Hof to help crush the Räterepublik. These were distributed on the streets, advertized at meetings, and published every day for several weeks in the Hofer Anzeiger. They warned that "unemployment, famine, rape, and plunder" would "accompany the Spartacist dictatorship" and described a "victorious Bolshevism" as "Armageddon for Europe and eventually the entire planet." 45 These appeals were not without success in convincing many locals to join paramilitary formations and fight "Bolshevism, the enemy of all values." 46 This kind of highly emotional, apocalyptic language and a willingness to take up arms had previously been conspicuous by its absence, even in January 1919, when a revolt of the radical left-wing Spartacus League (Spartakusbund) had brought considerable political violence to the streets of Berlin.

It was crucial that, on this occasion, the local Majority Social Democrats sided with the Bürgertum to oppose the Räterepublik, just as they had opposed the Spartacist uprising, and that, in some parts of Upper Franconia, joint demonstrations of the DDP and MSPD were held to protest the revolutionary disturbances across the state. ${ }^{47}$ Hof's burghers were evidently grateful for the support of moderate socialists, with Eduard Herold pouring scorn on the "villains" of the extreme left for their "denigration" of "old, proven working-class leaders" such as Friedrich Ebert and Johannes Hoffmann, the minister president of Bavaria. ${ }^{48}$ In the Hofer Anzeiger, Otto Ernst praised the "manful determination" of

Hof, April/Mai 1919 (henceforth Räterepublik Hofs), "Der Bolschewismus als Erlösungsreligion," April 29, 1919.

${ }^{43}$ StaHf ZA.2432, Räterepublik Hofs, "Ein wuchtiger Protest gegen die Raterepublik,” April 13, 1919.

44 "Die Lage in und um München," HA, April 26, 1919.

${ }^{45}$ StaHf ZA.2432, Räterepublik Hofs, "Aufruf des Bayerischen Schützenkorps," April 24, 1919.

${ }^{46}$ A "Hofer Mobile Protection Battalion" was successfully created, while an anti-Bolshevist meeting on April 23 resulted in a "large number" of young people registering at the local garrison for service. See StaHf ZA.2432, Räterepublik Hofs, "Auf gegen den Bolschewismus," April 23, 1919; "Bildung eines mobilen Schuetzen-Batlns. Hof," April 27, 1919.

${ }^{47}$ StaHf ZA.2432, Räterepublik Hofs, “Die Deutsche Demokratische Partei,” April 12, 1919.

${ }^{48}$ Herold, Ein Jahr deutsche Republik, 20. 
the MSPD's leaders and their party's development into a "highly principled, leading party of government." 49 The position taken by the MSPD during the Räterepublik therefore held certain advantages for the DDP, because it seemed to confirm their view that a deal could be struck with moderate socialists against the extreme left, which enhanced the perceived viability of parliamentary democracy. Should the MSPD move further to the left at some point in the future, however, and side with the apocalyptic "Bolshevist" threat, this vision would be severely compromised.

\section{The Treaty of Versailles and the 1919 Municipal Elections}

The Munich Räterepublik met a bloody end at the hands of regular and irregular troops at the beginning of May 1919. The growing sense of existential threat that it had imparted to Hof's middle classes was fatefully exacerbated, however, by the publication of the Treaty of Versailles just a few days later. It was telling that leading figures within the Hofer Bürgertum portrayed this not as a peace settlement or even as a punitive, merciless diktat, but rather as part of a deliberate policy of "extermination" (Vernichtung) designed to eradicate the German people. The Hofer Anzeiger described it as a "death sentence" and "the result of annihilatory politics"; the schoolteacher and poet Eduard Herold accused the Allies of aiming to "bury a great, free people"; while the Protestant synod denounced it as an "attempt to annihilate our very existence" by "reducing to slavery a two-thousand-year development toward freedom." 50

For the second time in the space of a month, then, words such as extermination and annihilation were appearing with startling regularity on the pages of the once staid Hofer Anzeiger and in the speeches of prominent local pastors and politicians. And, like the Räterepublik, the publication of the Versailles Treaty gave Hof's burghers a pretext for mass mobilization and agitation. Repeated protest meetings were organized by predominantly bürgerliche organizations: one such demonstration on May 13 attracted some three hundred people, and a resolution was passed calling on the German government to "refuse to sign this dictated peace." 51

It was decisive, however, that the position of the local Democrats on the matter of the Versailles Treaty proved problematically ambivalent. A party proclamation released in the immediate aftermath of the treaty's publication expressed "the unshakeable conviction that we should refuse [to give] our signature to these uncompromising enemies," despite "fully recognizing the consequences if we reject them." 52 But within weeks, Hof s DDP had realized that a failure to sign the treaty might trigger an Allied invasion of Germany, and they began to vacillate. By June, the DDP's Otto Ernst was arguing that "a compromise should be sought in which we sign but reject certain fundamental points," while other leading Democrats consistently refused to condemn those who ultimately agreed to sign it, with Karl Schrepfer insisting that "we must recognize the patriotic motives of those who believe they can spare Germany the worst by signing this document." ${ }^{3}$ Given the

\footnotetext{
49 “'Steine zum Aufbau," HA, June 14, 1919.

${ }^{50}$ See "Was soll nun Geschehen?," HA, May 10, 1919; “An Unsere Feinde!," HA, May 12, 1919; EvaDekHf, Evangelisches Gemeindeblatt, no. 6, "Der Diozesansynode Hof," May 11, 1919.

51 "Lokales und aus dem Kreise," $H A$, May 14, 1919.

${ }^{52}$ StaHf, ZA.2430, DDP Hofs, “Hof, 15. Mai," May 15, 1919.

53“Männer, nicht Menschen!," HA, June 21, 1919; StaHf, ZA.2430, DDP Hofs, "Deutsche Demokratische Partei: Bezirksvertretertag Oberfranken-Nordost,” June 15, 1919.
} 
DDP's initial uncompromising condemnation of the treaty, this newly-struck moderate tone constituted a worrying volte face before an audience which, over the past month, had heard Versailles described as the beginning of a process of "extermination." Indeed, as a party of rational moderation, Hof's Democrats' were ill-placed to exploit the storm of nationalist opprobrium that had greeted the publication of the treaty and seemingly destroyed the (quixotic) hope of a new world order built on international reconciliation.

That the Räterepublik and the Treaty of Versailles had weakened the DDP's position in Hof became uncomfortably apparent during municipal elections that took place in the summer of 1919. The Democrats now found themselves confronted by ostensibly "apolitical" middleclass interest groups that claimed to "stand above parties" and that attacked the DDP for being "needful of the milk of its liberal mother party." 54 The emergence of such groups was significant because, as several historians have shown, the claim to "apoliticism," to "stand above the parties," was a key aspect of Weimar political culture that frequently disguised fundamentally anti-republican intentions. ${ }^{55}$ Indeed, the leaders of "apolitical" formations such as the Neutral List (Neutrale Liste) and the District Burgher League (Gemeindebürgerverein) advocated a politics of "anti-Marxist" unity very different from the DDP's cooperative, pro-republican position. Such groups and their leaders were emboldened, especially by the recent experience of the Räterepublik, into once again showing their faces in Hof after some six months of lying low, and they performed well in the 1919 municipal elections, though they could not usurp the DDP as the dominant bürgerliche party in Hof.

There were, beyond the polls, further indications that the panicked fear of Bolshevism unleashed by the Räterepublik, and nationalist anger at the Versailles Treaty, had struck deep roots in the town. Later, in the summer of 1919, rumors began to circulate among local burghers of an "imminent Communist putsch." These whisperings found their way into the Hofer Anzeiger, which reported that the local Workers' and Soldiers' Council had drawn up a "list of sixty hostages who were to be arrested and shot," and that "massive shipments of weapons" had already arrived and been distributed among militant workers. A horrified Otto Ernst wrote that the "Bürgerschaft" was "in a state of unrest and excitement" because "such impractical putsch attempts are flaring up every day in Germany." 56 Indeed, despite angry denials by left-wing spokesmen, rumors continued to circulate, with one war veteran writing to the Hofer Anzeiger that he had overheard two communists talking in the park about their eager anticipation of the planned uprising. ${ }^{57}$

By the autumn of 1919, there were tentative signs that even darker forces had been awoken by the violent convulsions of the summer, as an "antisemitic movement" began to mobilize in Hof. ${ }^{58}$ The local chief of police wrote to the state ministries in Munich and Bamberg to voice his "grave misgivings" about this burgeoning movement, which was distributing leaflets blaming Jews for the Räterepublik and Germany's defeat, vandalizing

\footnotetext{
54،ZZur Gemeindewahl,” HA, June 14, 1919.

${ }^{55}$ Rudy Koshar, Social Life, Local Politics, makes the concept of "apoliticism" central to an analysis of the radicalizing Bürgertum. See also Hans Mommsen, Von Weimar nach Auschwitz: Zur Geschichte Deutschlands in der Weltkriegsepoche. Ausgewählte Aufsätze (Stuttgart: DVA, 1999), 108-35.

56 “Ist ein kommunistischer Putsch in Sicht?," $H A$, July 7, 1919.

57 “Eingesandt; Ist ein kommunistischer Putsch in Sicht?," HA, July 10, 1919.

${ }^{58}$ The upswing in antisemitic agitation that followed the collapse of the Räterepublik encompassed much of Bavaria in the last months of 1919. See Andreas Heusler, Das Braune Haus: Wie München zur 'Hauptstadt der Bewegung' wurde (Munich: DVA, 2008), 78-80.
} 
the synagogue, and holding "tumultuous" meetings. ${ }^{59}$ This kind of radical antisemitism continued to play a marginal role in Hof during the autumn of 1919, but it also constituted further disturbing evidence that the Räterepublik had not only stoked the flames of virulent anti-Communism among some of Hof's citizens, but also offered a lifeline to a radical right that had seemed dead and buried in the immediate aftermath of the war.

\section{The Kapp Putsch}

The Räterepublik and the Versailles Treaty brought an end to the DDP's honeymoon period in Hof, but it was the Kapp Putsch (and its aftermath) that delivered the fatal blow to the party's authority and credibility. On March 14, 1920, a group of army officers and rightwing politicians attempted to seize power in Berlin. In response, the republic's left-wing parties united and called for a general strike, which paralyzed the Reich's communication and transport networks, bringing a swift end to the putsch. In some parts of Germany, however, the strike quickly developed into a left-wing uprising, and near civil-war-like conditions prevailed throughout the spring of 1920. It was crucial that, in Hof itself, the leaders of the workers' movement—including, for the first time, the Majority Social Democrats—once again attempted to seize control of the town. But on this occasion, their uprising provoked a strong reaction from the Bavarian military.

Hof's Democrats initially opposed the putsch and supported the general strike. Otto Ernst sarcastically described Kapp's "adventure" as a "wonderful episode" undertaken by "the saviors of the Fatherland," who had been forced by the general strike "to realize that it is not possible to strike the will of the people in the face." ${ }^{60}$ And yet, this time there was to be no cooperation between the Bürgertum and the Majority Social Democrats, as there had been during the Spartacist uprising and the Räterepublik. Instead, the leaders of Hof's MSPD, USPD, and Communist Party met in the offices of the Oberfränkische Volkszeitung to issue a joint proclamation declaring that all power now lay in the hands of the Workers' and Soldiers' Council, demanding a "purely socialist government" for Germany, and calling for the disarming of the bürgerliche Einwohnerwehr (Home Guards). These paramilitary formations might, it was feared, serve as fifth columnists avant la lettre, if the army decided to march on the town. During the Kapp Putsch, then, the Majority Socialists made common cause with left-wing radicals, rather than opposing them in cooperation with the moderate Bürgertum. This was an understandable response if their aim was merely to combat the putschists, but their leaflet had gone further and demanded a new Räterepublik.

The following day, Leon Blumtritt, the leader of the Hofer Independent Social Democrats, repeated these demands at a protest meeting attended by several thousand people. After his speech, Blumtritt led his followers to the town hall, where he demanded, and was given, a list of local Home Guards members. The offices of the Hofer Anzeiger were then occupied and the newspaper censored for several days. ${ }^{61}$ The morning of March 15 saw armed workers climb into trucks and disperse to the towns and villages around Hof to confiscate the weapons of the Home Guards. This proceeded relatively peacefully in some places,

\footnotetext{
${ }^{59}$ StaHf, A.2928, “Antisemitische Bewegung," Nov. 27, 1919.

60 "Eine tolle Episode," HA, March 17, 1920.

${ }^{61}$ OV, 16. März 1920; Rabenstein, Politische und publizistische Strömungen, 84.
} 
but there was violence in others, with confrontations and even firefights between workers and burghers, leaving one dead and others badly injured. ${ }^{62}$

This violence made a profound impression on the local Bürgertum. In a speech before the municipal council on March 15, Mayor Karl Buhl complained that local burghers had been thrown into "a state of anxiety" by the attempted uprising, and denounced "the workers for overstepping their legal boundaries" in disarming the Home Guards. Otto Ernst gave a forlorn speech in which he lamented that Hof s burghers had been "prepared to work actively" to ensure that the "reactionary putsch" would not be successful: it had thus been "alienating and surprising" to the local Bürgertum that not one but "all three Socialist parties had also taken action against them" and called for a "Council Dictatorship," "terrorized salesmen and businesses, cut off the free press, demanded that all burghers give up their weapons," engaged in house searches, and brought about an "entirely one-sided arming of the working classes." 63

Unfortunately for the leaders of Hof's new "Soviet Dictatorship," the Bavarian military had long been waiting for a pretext to "cleanse the red corner of Upper Franconia." 64 On March 18, high-level decisions were taken to crush the left in Hof for good, and a military task force was assembled which included units of the regular army, as well as the so-called Chiemgauer Brigade, a notorious division of right-wing paramilitaries that had also participated in the crushing of the Munich Räterepublik the previous spring." ${ }^{65}$ On March 22, this force marched on Hof and took the town without resistance. At 5:30 in the morning, with Hof under military control, members of the Chiemgauer went to Blumtritt's flat, most likely with the intention of summarily executing him, but they found only empty rooms: the leaders of the local working-class movement had already fled across the border to Saxony. The next day, March 23, the Chiemgauer retraced the steps taken a few days earlier by local workers to the towns and villages around Hof, aiming to reclaim those weapons that had been taken from the Home Guards and avenge the "terror" that had taken place. They did this in an exceptionally brutal fashion in a number of locales, arresting those workers involved in the disturbances and beating many "to within an inch of their lives." 66

When the regular and paramilitary troops returned to southern Bavaria on March 25, they left in their wake a profoundly shocked and even more bitterly divided community. Whereas the working-class milieu appeared to have been cowed by the experience of military (and especially paramilitary) violence, the local Bürgertum was outraged, with Mayor Buhl arguing in a speech before the Municipal Council that the army's intervention had been justified because of the brutal conduct of Hof's working classes, which he described in lurid detail. ${ }^{67}$

\footnotetext{
62“Zur Lage,” HA, March 16, 1920; “Rehau, 16. März,” HA, March 17, 1920.

63 "Stadtrat und Vollzugsausschuss," HA, March 20, 1920.

${ }^{64}$ After the Räterepublik, discussions began at the highest levels of the Bavarian military about the prospect of an intervention in Hof to break the power of the left. See Rabenstein, Politische und publizistische Strömungen, 71-76.

${ }^{65}$ For a full account of the Chiemgauer's evolution and the attack on Hof, see David Clay Large, The Politics of Law and Order: A History of the Bavarian Einwohnerwehr, 1918-1921 (Philadelphia, PA: American Philosophical Society, 1980), 17, 39.

${ }^{66}$ Rabenstein, Politische und publizistische Strömungen, 90-94.

67 "Stadtvertretung und Staatskommissar," $H A$, March 25, 1920.
} 
Unlike the Spartacist uprising or Räterepublik, this time it was clear to everyone that the Majority Social Democrats had been a party to the "Red Terror" in Hof. The MSPD, a certain Herr Summerer admitted at a DDP gathering on April 25, had "shown their true face on the day of the putsch": it was now clear that the MSPD and USPD were "related by blood," concerned "only with a Socialist order and the dictatorship of the proletariat," and that the "union of the two parties" was "dearly desired, especially by the Majority Socialists." The MSPD, which had allied itself with the Bürgertum during the Spartacist uprising and the Räterepublik to resist the far left, had now become "a party that sharply fights against democracy," one that "could not be brought to reason" by a "politics of reconciliation." At this same meeting, a local factory owner named Pensel stood up to declare angrily that the DDP's attempted "division of Majority Socialists from the USPD" was "only superficial," and that there could be no further confusion about how the Bürgertum "should deal with the left." 68

Indeed, this assessment of the local MSPD was seemingly confirmed by developments on the regional and national levels, where the two socialist parties seemed to be moving closer together after years of mutual antagonism. In the wake of the Kapp Putsch, the MSPD and USPD organized several joint demonstrations and coalitions in towns and villages across Upper Franconia, while, at the national level, there was also a perceptible drift leftward: as the Hofer Anzeiger put it, "influential tendencies in the MSPD are now so far to the left that they are already in the camp of the Independents." 69 Indeed, the newspaper warned that a left-wing Reichstag majority consisting of "not just the Independents and Communists but also of the leftward moving Majority Socialists" would produce "civil war," with "the radicals ... climbing over thousands of corpses to bring about the Red Räterepublik."70

The MSPD's leftward trajectory, and the apparent formation during the Kapp Putsch of a unified "Marxist" front stretching from Communists to Majority Socialists, was enormously problematic for Hof's Democrats, whose entire model of politics was built on the idea of cooperation with moderate Socialists in the construction of a democratic republic. The events of the Kapp Putsch seemed to suggest that the political fault lines ran not between moderates and radicals but between left and right, just as they had during the Kaiserreich. Hof's burghers might reasonably question the credibility of a political party that claimed to function as a bridge between burghers and workers when the latter were bent on "the complete annihilation of the middle classes," as one local businessman put it at meeting of Hof's Business Association (Gewerbeverein). ${ }^{71}$

To make matters worse, events in Hof took place within the context of considerable revolutionary violence across the Reich as a whole. In the days after the dissolution of the "Hofer Räterepublik," the Hofer Anzeiger was filled with bloodcurdling details of what sounded like an unfolding civil war. It contained reports of working-class uprisings in Dresden, Leipzig, Stettin, Kiel, and Berlin, but its most extensive reporting focused on the Ruhr industrial region, where a ten-thousand strong "Red Army of the Ruhr" appeared to be running amok. ${ }^{72}$ The

\footnotetext{
${ }^{68}$ StaHf, ZA.2430, DDP Hofs, "Bezirksvertretertag der Deutschen Demokratischen Partei,” April 25, 1920.

69"Lokales und aus dem Kreise," HA, March 27, 1920; "Lokales und aus dem Kreise," HA, April 16, 1920.

70 "Wahlen und Waffen," $H A$, April 27, 1920

71 "Das Reichsnotopfer," HA, April 24, 1920.

72 “Zur Lage im Reiche,” HA, March 17, 1920; “Zur Lage im Reiche,” HA, March 19, 1920; “Zur Lage im Reich," $H A$, March 3, 1920.
} 
Anzeiger began to run military-style maps which showed the frontlines around towns such as Essen and Bochum, just as it had published maps of the Western Front during World War I. ${ }^{73}$ The "question of the Ruhr and the terror of the Communist leadership," Otto Ernst wrote in his Easter editorial, had become "a Golgotha for the German Reich."74

To Hof s burghers, however, the most disturbing manifestation of this "civil war" came in the nearby Saxon Vogtland, an area immediately to the north of the town. The Kapp Putsch had led there to the creation of the "Red Army of the Vogtland" under the leadership of Max Hölz, a local communist. ${ }^{75}$ The Hofer Anzeiger provided daily reports of Hölz's astonishing exploits, which included firefighting with the police, extorting money from prominent local Burghers, hostage-taking, setting fire to bürgerliche property, and generally causing mayhem in the name of a nebulously defined "communism." 76 Hölz's uprising ultimately met its end as well at the hands of the Bavarian military, but his "reign of terror" had left the middle-class citizens of the region thoroughly restless. ${ }^{77}$

To Hof s burghers, the events that took place in the spring of 1920 seemed to hold not only a local, regional, and national, but also an increasingly international significance, because the Red Army was on the march at the time in Eastern Europe. "The advance of the Red Army of the Ruhr," the Hofer Anzeiger alleged, would "go hand-in-hand" with a Russian advance against Poland, and, "by July, [Leon] Trotsky hopes to be at the gates of Berlin." "78 Indeed, as far as the Anzeiger was concerned, the Bolsheviks were the real puppet masters in the Ruhr, and there could be no doubt that "the current struggle of the Red Army of the Ruhr follows a unified, fiendish, brutally power-hungry Russian conspiracy." These disturbing details were accompanied by grisly atrocity stories emanating from Poland and Ukraine, where "members of the bourgeoisie" who fell into Bolshevik hands were supposedly "gruesomely murdered."79 The Protestant newsletter proved especially assiduous when it came to detailing Bolshevik outrages in Eastern Europe, with one article describing mass shootings, live burials, and drownings, closing with the dire warning that "the next gateway of Bolshevism will be Germany." 80

It is important to take these developments together-the leftist uprising in Hof itself, the disturbances in the Vogtland, the tumult in the Ruhr, the advance of the Red Army in Eastern Europe - and consider what effect they might have had on Hof's national-protestant milieu. It is also crucial that these convulsions came within the context of the series of revolutionary uprisings that had taken place over the previous eighteen months, as well as of the "exterminatory" Treaty of Versailles. The "end times," it seemed, had arrived, with one local journalist remarking darkly on the "astonishing similarities between these days and what had happened in Russia" prior to the Bolshevik Revolution, with Germany, it seemed, "heading the same way." 81 Could the viability and credibility of the DDP's model of politics- their

\footnotetext{
73“"Vom Kampfgebiet an der Ruhr," HA, April 10, 1920.

74، Zwischen Karfreitag und Ostern," HA, April 3, 1920.

${ }^{75}$ Even today Hölz remains a controversial figure: some still "see him as a hero, others merely as a criminal." See Michael Seifert, "Kesselheizer der Revolution,” Historikus Vogtland (Aug. 2009): 8-14.

${ }^{76}$ See, e.g., "Plauen, 5. April," HA, April 7, 1920; “Die 'Heldentaten' des 'Volksbeglückers' Hölz," HA, April 12, 1920.

77 “Hölz im Marienbad ergriffen,” HA, April 19, 1920.

78 "Die Lage im Rheinland-Westfalen," HA, March 29, 1920.

79،"Ausland," HA, May 21, 1920.

${ }^{80}$ EvaDekHf, Evangelisches Gemeindeblatt, no. 9, "Der Christenhass des Bolschewismus," April 25, 1920.

81 "Wahlen und Waffen," HA, April 27, 1920.
} 
republican vision of cooperation with the MSPD and international reconciliation-possibly survive in such an atmosphere?

\section{The 1920 Reichstag Elections}

When campaigning began for the Reichstag elections of June 1920, Hof's Democrats came under heavy attack for their conduct over the previous eighteen months. At a DDP meeting on April 26, the local factory owner named Pensel denounced "the work of the Democrats" for being "far too considerate of the Majority Socialists," while others accused the party of being overly fulsome in its initial support for the left-wing general strike after the Kapp Putsch. ${ }^{82}$ Karl Schrepfer felt compelled to defend himself against "accusations that we betrayed the Bürgertum"; Councillor Meisner insisted, for his part, that "it is an absolutely unjustified accusation that we have been little more than an appendix of the Social Democrats," with Dr. Luppe angrily contesting "the constant accusation that we position ourselves too closely to the Majority Social Democrats." 83 These denials only highlighted the DDP's vulnerability, given that the fundamental basis of their conception of politics was cooperation with the MSPD to create a democratic republic. To Hof s burghers, recent events had rendered such a position not only dubious but also positively perilous.

To make matters worse, the Democrats now found themselves up against a viable competitor in the form of the right-wing nationalist Bavarian Middle Party. In the run-up to the 1920 elections, the BMP conducted an explicitly "monarchist-anti-republican" and "antisemitic" campaign across Upper Franconia, which appeared to be resonating with a Protestant Bürgertum newly inflamed by the experiences of the previous months. ${ }^{84}$ In Hof, too, local burghers proved more susceptible to the BMP's message than ever before. The Democrats were still able to dominate the town's political infrastructure: they continued to hold many more meetings, they controlled the municipal council, and they enjoyed the backing of the local newspaper. But the BMP was building a solid following in the communes around Hof, and it could present itself much more plausibly than the DDP as a genuinely "anti-Marxist," conservative, and nationalist party. ${ }^{85}$

The BMP held only one pre-election gathering in Hof, but its appeal was abundantly evident to all who attended (which included a rattled Otto Ernst). At this meeting, Dr. Hermann Strathmann, a regional speaker of the BMP and one of the party's founders, lambasted the republican state form and argued that the responsibility for its flaws lay largely at the door of the Democrats, under whom Germany was "already approaching a dictatorship of the proletariat." 86 Strathmann repeatedly stressed the "holding high of nationalist thinking" and a ceaseless battle "against enervating internationalism," while calling for a full restoration of the Church's dominance in the field of education and showing himself to be a

\footnotetext{
${ }^{82}$ StaHf, ZA.2430, DDP Hofs, 1918-1924, "Bezirksvertretertag der Deutschen Demokratischen Partei," April 25, 1920; "Erklärung," $H A$, May 8, 1920.

${ }^{83}$ StaHf, ZA.2430, DDP Hofs, 1918-1924, "Bayerische Politik in der Gegenwart und Zukunft," May 28, 1920; "Was kann uns retten aus unserer Not?," June 4, 1920; "Demokratie und Nationalversammlung," May 31, 1920.

${ }^{84}$ Kittel, "Weimar" im evangelischen Bayern, 66.

85 “Morgenpost," HA, June 3, 1920.

${ }^{86}$ On Strathmann's career in the BMP, see Manfred Kittel, "Zwischen völkischem Fundamentalismus und gouvernementaler Taktik. DNVP-Vorsitzender Hans Hilpert und die bayerischen Deutschnationalen," Zeitschrift für bayerische Landesgeschichte 59 (1996): 858.
} 
proponent of the "stab-in-the-back" legend. ${ }^{87}$ Ernst's subsequent report in the Hofer Anzeiger was scathing, but there was little doubt that the local Democrats were unsettled, especially as reports continued to filter in of the warm response received by nationalists in the rural communes around Hof. ${ }^{88}$

The election results were announced on June 7 and, despite the BMP's limited campaigning in Hof, they still managed to increase their votes in the town from 190 in January 1919 to 1,336. Most of these had almost certainly come from the Democrats, who recorded a drop of 13 percent vis-à-vis their 1919 share. The mood of the members of Hof s DDP was consequently sombre, with local Democrats asking what might have happened had the BMP devoted more substantial resources to campaigning in the town itself, and had the local newspaper conducted itself in a less partisan manner. Something resembling this scenario had obtained in the small towns and communes around Hof, in places such as Rehau, Marktredwitz, Münchberg, Kulmbach, and Naila, and here the Democrats had been more or less wiped out electorally by the German Nationalists. To make matters worse, this all came against the backdrop of the national and regional results, where the DDP had experienced severe setbacks and been almost nullified as a political force in some parts of the Upper Franconian countryside. ${ }^{89}$

Overall, then, it was clear which way the wind was blowing, and the Hofer Anzeiger's leading article rightly recognized these results as a "catastrophe" for the DDP. ${ }^{90}$ Indeed, these elections ultimately heralded a political and discursive shift within Hof's nationalprotestant milieu from democratic republicanism to radical nationalism. Over the next twelve months, attendance at DDP meetings declined precipitously and, by early 1921, the party was in severe financial difficulties. ${ }^{91}$ On only one occasion after 1920 would the party manage to poll more than a thousand votes in the town and, in the elections held in the summer of 1932, just 109 people endorsed the DDP. By contrast, the Bavarian Middle Party opened a local chapter in September 1920 and, within six months, its membership had increased twelvefold from twenty-five to some three hundred people. By 1922, this figure would reach more than a thousand. ${ }^{92}$

The contrasting fortunes of the Democrats and Nationalists were not the only indication that the mood among Hof's burghers had shifted in a more aggressively nationalist and antiSocialist direction in the wake of the Kapp Putsch. On May 31, the Naval Veterans' Association (Vereinigung ehemaliger Marine- und Schutztruppen-Angehöriger für Hof und Umgegend), which was closely connected to the Bavarian Middle Party, held a "Skagerrakfeier," a celebration of the 1916 Battle of Jutland between the navies of Germany and Britain. This event had been planned in January 1920, and was initially intended as a "simple memorial service" for the association's modest membership, but, to

\footnotetext{
${ }^{87}$ StaHf, ZA.2431, Dokumente der Bayerische Mittelpartei Hofs, 1918/1924 (henceforth BMP Hofs), "Warum ... Die Bayerische Mittelpartei," May 29, 1920.

${ }^{88}$ StaHf, ZA.2431, BMP Hofs, “Die Wahlbewegung,” June 4, 1920; “Morgenpost,” HA, June 3, 1920.

${ }^{89}$ See "Der Stimmenzuwachs nach rechts und ganz links auf Kosten der Mitte," HA, June 8, 1920. For the Upper Franconian context, see Kittel, "Weimar” im evangelischen Bayern, 69-70.

90 “Weitere Wahlresultate," HA, June 9, 1920.

${ }^{91}$ See, e.g., StaHf, ZA.2430, DDP Hofs, "Hof, 12. November 1920"; "Hof, 24. Februar 1921."

${ }^{92}$ StaHf, ZA.2431, BMP Hofs, "Von der Hauptversammlung der Bayerischen Mittelpartei, Ortsgruppe Hof," May 14, 1921; "Hof, 24. Mai 1922. Die Jahreshauptversammlung der Ortsgruppe Hof der Bayerischen Mittelpartei," May 24, 1922.
} 
the surprise of the organizers, it filled the entire hall they had rented for the occasion. The "commemoration" turned out to be a bellicosely nationalistic gathering that unambiguously celebrated Germany's war experience and, though it was not explicitly mentioned, quite clearly constituted a rejection of the revolution. ${ }^{93}$ During the eighteen months after the end of the war, militaristically colored events such as these had only attracted limited attention in Hof but, after the summer of 1920, they became more frequent occurrences, with flag consecrations and mass marches by veterans' and warriors' leagues growing in number. ${ }^{94}$

It is significant that such events, as well as the meetings of the Bavarian Middle Party, would soon enjoy the support of the local newspaper. In July 1920, Otto Ernst, the editor of the Hofer Anzeiger and a prominent Democrat, left his post. It is unclear if he did so of his own volition, or if he was removed by the paper's owners, who were evidently hoping to shift its editorial content to the right. ${ }^{95}$ In any event, he was replaced by Karl Röder, an avowed nationalist who attacked the "parliamentary miscarriage" visited on Germany in 1918 and argued that military force was the only viable way to settle international disputes. ${ }^{96}$ Indeed, this shift was even evident in the writings of individual burghers: Pastor Dietrich, editor of the "Protestant Newsletter," began to publish increasingly intemperate articles fulminating against "Jewish Bolshevism," while the poet and teacher Eduard Herold, who had once praised the League of Nations as "the most German idea ever thought," became a key speaker at paramilitary meetings, where he inveighed against Marxism and called for vengeance against France. ${ }^{97}$

By the close of 1921, little remained of the democratic consensus that had seemed so firmly entrenched just three years earlier. The DDP had become a spectral presence in local politics, haunting thinly populated meetings halls; men in military uniform gathered at local war memorials to consecrate the imperial flag; the local newspaper and Protestant newsletter had become organs of nationalist ideology. The future of politics in Hof belonged to organizations such as the Bavarian Middle Party, right-wing paramilitary leagues and ultimately, of course, the National Socialists, who were able to flourish in a state that increasingly developed into a safe haven for right-wing anti-republicanism under the Catholic-conservative Minister President Gustav von Kahr. ${ }^{98}$

\section{Conclusion}

This article began by posing two questions. First, how successful was the German Democratic Party in imposing its political narratives and interpretations in Hof, and to what extent did the party's early success reflect a genuine (if preliminary and cautious) commitment to democratic and republican values on the part of Hof s Bürgertum? The contention of this article is that, in the autumn of 1918, the mood among Hof's burghers was war-weary, very

\footnotetext{
${ }^{93}$ StaHf, ZA.2433, Militärische, vaterländische und völkische Verbände Hofs, 1918-1924 (henceforth Verbände Hofs), "Vereinigung ehemaliger Marine und Schutztruppen-Angehoriger für Hof und Umgegend, 'Skaggerak-Feier in Hof,", June 1, 1920.

${ }^{94}$ See, e.g., StaHf, ZA.2433, Verbände Hofs, “Den Toten unserer Stadt," Nov. 1, 1920.

${ }^{95}$ Rabenstein, Politische und publizistische Strömungen, 151.

96 "Parlamentarische Fehlgeburt," HA, April 12, 1921; "Politische Wochenübersicht," HA, July 2, 1921.

${ }^{97}$ EvaDekHf, Evangelisches Gemeindeblatt, no. 7, "Aus Kirche und Welt," April 6, 1924; StaHf, ZA.2433, Verbände Hofs, "Die vaterländische Kundgebung in Wirsberg," July 28, 1923.

${ }^{98}$ See Martin H. Geyer, Verkehrte Welt: Revolution, Inflation und Moderne, München 1914-1924 (Gottingen: Vandenhoeck \& Ruprecht, 1998), 112-17.
} 
receptive to extensive democratic reform of the political system, and thoroughly disenchanted with both the monarchy and those radical nationalists who had consistently called for an aggressive war of annexation. The Democrats proved adept at tapping into this preexisting mood and asserting their claim to be the leading party of Hof's national-protestant milieu.

The second question asked why bürgerliche support for the DDP in Hof collapsed so suddenly and spectacularly. As the foregoing suggests, Democratic narratives-around international reconciliation and cooperation with the moderate left-suffered a severe Plausibilitätsverlust ("loss of plausibility") because of three catastrophic crises that hit the town beginning in the spring of 1919: i) revolutionary unrest in Hof and Bavaria triggered by the creation of the Munich Räterepublik, which gave rise to a "civil war" mentality among Hof's burghers and injected an apocalyptic anti-Bolshevism into local discourse; ii) the publication of the Treaty of Versailles, which discredited the idea that future relations with the Allies could be built on a peaceful and reconciliatory foundation; and, above all, iii) the revolutionary unrest surrounding the Kapp Putsch, which not only further stimulated the existing "civil war mentality," but also deepened it further because of the involvement of the Majority Social Democrats. ${ }^{99}$ Together, these developments eroded and then destroyed support for the DDP's platform, while making radical nationalist positions seem ever more credible.

These findings are a corrective to those studies that have emphasized the fundamental authoritarianism of the German Bürgertum. There is considerable evidence that, in Hof at least, democratic and pro-republican ideas had a chance of enduringly establishing themselves within the national-protestant milieu. This is not to contend that every burgher in Hof awoke on the morning of November 10,1918, to suddenly find that they were all committed parliamentarians, but rather that the events of the preceding years had made this section of the population much more receptive to the idea of democratic reform. Under more conducive conditions, the DDP may have been able to transform this potential into a long-term commitment to the new republic. That this did not transpire is explicable chiefly with reference to the atmosphere of crisis and violence that descended upon Hof and Germany from the spring of 1919, which was critical for bringing about the formation of a radical nationalist, anti-republican mobilization in the town.

But does this mean that bürgerliche radicalization in the Weimar Republic was a straightforward reaction to the threat of left-wing violence? As the literature on this phenomenon during the Weimar Republic shows, there was considerable regional variety here-for every Hof there was a Marburg, where revolutionary violence was almost unheard of and where the local Bürgertum nonetheless still drifted in a radical nationalist direction. ${ }^{100}$ Yet, even in places that did not directly experience political violence, local burghers heard rumors or had access to newspapers that carried reports of such violence elsewhere in the Reich and beyond. Given that, and judging by the evidence presented here, it is reasonable to suggest that, in many places, the pervasive violence (both real and perceived) of the opening years of the Weimar Republic was central to the eclipse of the Democrats and

\footnotetext{
${ }^{99}$ On the idea of a Plausibilitätsverlust, see Willibald Steinmetz, "40 Jahre Begriffsgeschichte-The State of the Art," in Sprache, Kognition, Kultur: Sprache zwischen mentaler Struktur und kultureller Prägung, ed. Heidrun Kämper and Ludwig M. Eichinger (Berlin: De Gruyter, 2008), 188.

${ }^{100}$ See Koshar, Social Life, Local Politics.
} 
the ensuing process of bürgerliche radicalization in the German provinces - and that we cannot understand that process without setting it within the overall context of the massive violence that characterized the opening phase of the Weimar Republic. This observation gives rise to yet another question, of course, but one that goes beyond the remit of this article: how did the discursive and organizational structures imparted to the German Bürgertum by the revolutionary violence of the republic's early years feed into the rise of the Nazis some ten years later?

University of SAint ANDREws 